\title{
Experience of Female Genital Cutting and Sexual Satisfaction Among Rural Married Women in El Beheria Governorate
}

\author{
Amal Yousef Abd Elwahed ${ }^{1}$, Wesam Kamal Ali ${ }^{2} \&$ Violet Nicola Ghattas ${ }^{2}$ \\ ${ }^{1}$ Community Health Nursing, Faculty of Nursing, Damanhor University, Egypt \\ ${ }^{2}$ Obstetric and Gynecologic Nursing, Faculty of Nursing, Damanhor University, Egypt \\ Correspondence: Amal Yousef Abd Elwahed, Lecturer, Community Health Nursing, Faculty of Nursing, \\ Damanhor University Egypt.
}

Received: January 21, 2019

Accepted: February 14, 2019

Online Published: February 20, 2019

doi:10.20849/ijsn.v4i1.546

URL: https://doi.org/10.20849/ijsn.v4i1.546

\begin{abstract}
Background: Female Genital Cutting is a complex issue requiring continuing care for girls and women who may be at risk or may have been undergone this harmful practice.

Objective: Assess the experiences of Female Genital Cutting and its relation to sexual satisfaction among rural women in El Beheria Governorate.

Design: cross-sectional descriptive design.

Settings: The study was carried out at 16 rural health units representing the 16 health zones in El Beheria Governorate.

Subjects: A convenience sample of 800 women selected from the previously mentioned setting (50 from each health unit).

Tools: Two tools were used for data collection. The first tool was women's experience of FGC structured interview schedule to identify data related to personal and socio-demographic characteristics, their experience of FGC, as well as their attitude towards FGC, which was assessed through 21 statements in three points Likert scale. The second tool was sexual satisfaction Scale to assess the sexual satisfaction among the married women.

Results: Findings of the present study revealed that the majority (90.0\%) of the women had undergone FGC. Moreover, less than two thirds (63.0\%) of the women had positive attitude toward combating FGC. Additionally, around one tenth $9.8 \%$ of the women suffered from low sexual satisfaction compared to $18.4 \%$ of them who had high satisfaction. Moreover, significant correlations were found between women's experience of FGC and their attitude toward it as well as with their sexual satisfaction.

Conclusion: The study concluded that FGC is highly prevalent practices among rural women. There are a significant association between women's experience of FCG and their attitude towards it as well as with the women's sexual satisfaction.
\end{abstract}

Keywords: female genital cutting, rural areas, violence against women

\section{Introduction}

Women represent half of the society. They are the cornerstone of the family and assume responsibility for many of its most function, not only in regard to health and education, but also in food production and income generation. Therefore, the health of the women is prerequisite for the health of the whole family and by extension of communities and societies (United Nations, 2014).

Women health is often characterized by neglect, abuse, violence, and discrimination. Women are vulnerable to violence and its profound effect at all stages of life (United Nations, November 2018).

Violence against women and girls is perhaps the most widespread and socially tolerated patterns of human right violation. It remains a key global public health problem associated with poor physical, sexual and mental outcomes for victims and has potential negative lifelong consequences (United Nations November 2018; Guimei, Fikry \& Esheiba, 2012).

Throughout the last two decades, women health became a major concern for the international society in order to 
end all forms of violence against women including Female Genital Cutting (FGC) (United Nations, November 2018; September 2018).

Female Genital Cutting (FGC) is one of the most traditional practices which is harmful to health and is profoundly rooted in many Sub- Saharan African countries. It is estimated that more than 200 million girls and women alive today have undergone female genital mutilation in the countries where the practice is concentrated. Furthermore, there are an estimated 3 million girls at risk of undergoing female genital mutilation every year. The majority of girls are cut before they turn 15 years old. (UNICEF, 2016; WHO, 2018)

The practice of Female Genital Cutting is still widely prevalent in Egypt despite efforts to eradicate it. According to Egypt Demographic Health Survey (EDHS) 2015, the prevalence of FGC among ever married women aged 15 to 49 years is $78 \%$. Furthermore, it more prevalent in rural governorates where its prevalence reaches $92.6 \%$ (El Zanaty 2015).

Unlike most other countries where FGC is prevalent, in Egypt, the practice is performed mainly by medical personnel. According to the EDHS 2015, around two thirds of the circumcisions performed by trained medical personnel. However, Daya was performing more circumcision in rural areas (El Zanaty, 2015; UNICEF, 2013)

The reasons given to justify FGC are numerous and reflected the ideological and historical situation of the societies in which it has been developed. Reasons cited are generally related to tradition, power in equalities. Additional causes may include maintaining tradition, reducing sexual desire, hygiene, cleanness, and religious approval (Yirga, Kassa, Welday et al 2012; Berg \& Denison, 2013)

The immediate and long-term health consequences of FGC vary according to the type and severity of procedure performed. However, all types include both physical and psychological, sexual consequences. It may result in sever deterioration of the current and future quality of life. The consequences of this harmful practice can range from infection to problems in child bearing and marital life (WHO, 2011)

Female genital mutilation (FGM) is a deeply rooted tradition in Egypt, and is a problem that matters a lot and that needs to be studied and understood. Assessing the experience and attitude of FGC and its consequences among the main victims is a very important measure towards the movement of discharging this long held tradition from the society which is suffering from its immediate as well long-term consequences. It has a great significance in the preparation for bringing an attitude change in mothers and to empower them above all by understanding that most common reasons for the practice of FGM stem from direct or indirect attitude of down grading women and looking at them as beings created to serve the other sex and it is this social attitude which is playing an important role that needs to be destroyed in order to achieve at behavioral change (UNICEF, 2018; Varol, Fraser, Jaldesa et al 2014)

Improvement of maternal health is incorporated in the sustainable development goals (SDG) as one of the prerequisites for development and poverty reduction (Byrne,2013; Edouard, Olatunbosun, Edouard 2013) The study results will be used at all levels that are hoped to play a part in the improvement of maternal health which is the main role of the community health nurse.

Female Genital Cutting is a complex issue requiring vigilance and continuing care for girls and women who may be at risk or may have been undergone this harmful practice (United Nations, November 2018). Through frequent and intensive contact with clients in different settings, community health nurses are in a prime position to act on prohibition of this harmful practice. Community health nurses play a crucial role in preventing FGC through promoting girls' and women's health and identifying those who are at risk for FGC and taking action to protect them (McCrae and Bynoe 2015; Clark 2008)

\subsection{Aims of the Study}

The aim of the study is to:

1. Assess the experiences of female genital gutting among rural women in El Beheria Governorate.

2. Identify the effect of female genital cutting on marital and sexual life satisfaction.

\subsection{Research Questions}

1. How do rural women who have undergone female genital cutting perceive the practice?

2. What is women's attitude towards FGC?

3. What is the effect female genital cutting on marital and sexual life satisfaction? 


\section{Materials and Method}

\subsection{Materials}

\subsubsection{Research Design}

The cross-sectional descriptive design was adopted to carry out this study.

\subsubsection{Setting}

The study was carried out at 16 rural health unit/center representing the 16-health district in El Beheria Governorate. The selected units have the highest attendance rate. They are illustrated as follow;

\begin{tabular}{ll}
\hline \multicolumn{1}{c}{ Health district } & \multicolumn{1}{c}{ Selected health center } \\
\hline Abo El Matameer & El huria \\
Housh Isa & Elkom elakhder \\
El Delingate & Zaweyt Hammour \\
El Tahreer & Abobaker elsedeek \\
West El Noubarya & Biesar \\
El Natroan Valley & Elhamraa \\
Damanhour & Kfr Bny Helal \\
El Mahmoudya & Sronbay \\
Abo Homous & Gwad hosny \\
Kafr Eldawar & Kom elbraka \\
El Rahmanya & Somokhratt \\
Shoubrakhiet & lakanh \\
Kom Hamada & Saftt elenb \\
Itay Al Baroud & Elawamer \\
Edco & Elmaadia \\
Rosetta & Mahlt Elamir \\
\hline
\end{tabular}

\subsubsection{Subjects}

- The sample size was estimate using Epi info 7 statistical program using the following parameters; prevalence of FGC 78\%, with $99 \%$ confidence level and 5\% maximum error. The minimum sample size estimated to be 673 women. The final sample size will be 800 women to compensate for possible non-response.

- A convenient sample of 50 married women were selected from each of the previously mentioned settings. Married women should be willing to participate in the study.

\subsubsection{Tools for Data Collection}

In order to collect the necessary data for the study three tools were used:

Tool (I): Women's experience of FGC structured interview schedule: It was developed by the researchers to collect the necessary data from the married women. It included two parts:

First part: Married women's personal and socio-demographic data: It included the age, level of education, occupation, income, living condition and husband's age, level of education and occupation, religion.

Second part: Women's experience of FGC: It included data about experiences of FGC, person conducting FGC, place and time of conducting FGC, causes behind acceptance/ non-acceptance of FGC, health problems experienced during and after circumcision and their intent to circumcise their daughters.

\section{Third part: Women's attitude towards FGC:}

It was developed by the researchers after reviewing of recent literatures. It is a three-point Likert scale with 21 statements related to the following domains; societal \& religious beliefs about FGC ( 3 items), Benefits of FGC (6 items), Consequences/harms of FGC ( 8 items), and Own and community support of FGC (4 items). Participants should indicate the extent of their agreement or disagreement with each statement using a three-point Likert scale ranging from agree, undecided and disagree. The scoring was as follows: agree (2), undecided (1), and disagree (0). The total score was calculated and converted into percent score classified as follow, women with positive attitude towards FGC (those who discourage FGC) were those who had total attitude $\%$ score $\geq 50 \%$ score. On the other hand, those with negative attitudes towards FGC (those who 
encourage FGC) were those who had total attitude $\%$ score $<50 \%$ score.

\section{Tool (II): Sexual Satisfaction scale:}

It was developed by the researchers after reviewing of recent literatures. The sexual satisfaction scale comprised 9 questions with three responses [ agree $=(2)$, undecided $=(1)$ and disagree $=(0)$ ]. The total score of sexual satisfaction scale distinguished between low satisfaction (score 0-6), moderate satisfaction (score 7-13) and high satisfaction (score 14-18).

\subsection{Method}

- Approval of responsible authorities was obtained through official letters from the Faculty of Nursing.

- Meetings were held with the directors of the selected settings to clarify the purpose of the study and to gain their cooperation and support during data collection.

- Tool (I) and (II) were developed by the researchers after reviewing the recent relevant literature. It was validated by juries of (5) experts in the field. Their suggestions and recommendations were taken into consideration.

- Cronbach Alpha Coefficient was used to ascertain the reliability of tool (I) parts (II and III) and (II) after translation into Arabic language, $(r=0.89$ for tool I part I, $r=0.83$ for part III and 0.91 for tool II).

- Pilot study was carried out on 80 women who were randomly chosen from a family health center not included in the sample namely, "Sharnoub in Damanhour, Feesha in Elmahmoudya and om hakim in Shoubrakhiet " in order to ascertain the relevance, clarity and applicability of the tools, test wording of the questions and estimate the time required for the interview. Based on the obtained results, the necessary modifications were done.

\subsection{Ethical Considerations}

- Informed oral consents were obtained from the married women after brief explanation of the purpose and nature of the research.

- The anonymity and confidentiality of responses, voluntary participation and right to refuse to participate in the study were emphasized to women. The researcher explained the objectives of the study to the participants.

- Data was collected by the researchers during the period from January 2018 to May 2018 (18 weeks).

\subsection{Statistical Analysis}

- After data were collected, they were coded and transferred into specially designed formats so as to be suitable for computer feeding. Following data entry, checking and verification processes were carried out to avoid any errors during data entry, frequency analysis, cross tabulation and manual revision were all used to detect any errors. The statistical package for social sciences (SPSS version 20) was utilized for both data presentation and statistical analysis of the results. The level of significance selected for this study was P equal to or less than 0.05 .

\section{Results}

Table 1 shows that less than half (45.2\%) of the women aged less than 30 years old, while $17.8 \%$ of them aged forty years and more with a mean of $32.45 \pm 7.203$. The vast majority (96.2\%) of the women were Muslims and more than half $(54.5 \%)$ were urban dwellers. Concerning their educational level, the table shows that more than one quarter $(27.4 \%)$ of them were illiterate or just could read and write while those who completed their university education constituted $15.5 \%$. On the other hand, $85.7 \%$ of them were housewives. The table also portrays that $25.8 \%$ of the women's husbands were illiterate and the vast majority (97.5\%) of them were working. Furthermore, the table reveals that the mean marriage age for the studied women was $21.65 \pm .3 .245$ and more than one third (37.8\%) of the women had been married for less than 5 years, while the mean family size was $4.52 \pm 1.348$. Additionally, less than three quarters $(72.0 \%)$ of the studied women reported income insufficiency and $15.3 \%$ of them were of lower social level compared to $22.3 \%$ of them who were of high social level.

Table 2 portrays the experience of FGC among the studied women. It was found that the majority (90.0\%) of the studied women had undergone FGC and around one fifth (20.8\%) of them had undergone FGC at age of less than ten years, compared to $25.7 \%$ of them who were circumcised at age of fifteen years and more. Furthermore, the table illustrated that more than one third (35.0\%) of the circumcised women had the procedure done by physicians, while Daya /traditional birth attendant (TBA) had conducted FGC for $38.6 \%$ of them. The same table shows that all women mentioned that their opinion was not taken before the procedure and $80.0 \%$ of them were 
circumcised at home. Furthermore, two fifths $(40.0 \%)$ of the women experienced immediate consequences of FGC mainly pain, urinary problems and fear $(75.0 \%, 59.7 \%$ and $47.9 \%$ respectively). Lastly, more than one quarter $(29.7 \%)$ of the circumcised women mentioned that they suffered from FGC's long-term complications, mainly diminished sexual pleasure, dyspareunia as mentioned by $73.8 \%$ and $47.7 \%$ of them respectively.

Table 2 illustrates the experience of FGC among the studied women's daughters. It was noticed that among those who have daughters, more than half (51.6\%) of them had undergone FGC for their daughters and the decision for FGC taken mainly by grandparents $(66.0 \%)$ followed by mothers themselves $(50.3 \%)$ and fathers $(23.4 \%)$. One the other hand, less than three quarters $(73.1 \%)$ of them was circumcised by physicians and the rest with circumcised by Daya or Traditional birth attendants, while, less than three quarters (72.8\%) of them experience immediate complications after FGC in the form of psychological shock (31.7\%) and fever (25.4\%). Concerning the causes for FGC, it was mainly for religious requirement, preserve pureness and chastity, and social tradition as mentioned by $76.9 \%, 58.7 \%$ and $53.5 \%$ of them respectively.

The same table portrays that young age of the daughters, fear of complications and fear of law criminalization were the main causes mentioned by those who did not perform FGC for their daughters $(60.6 \%, 33.3 \%$ and $18.8 \%$ respectively). On the other hand, $61.7 \%$ of those women claimed that they have the intention to perform FGC to their daughters in the future.

Figure 1 portrays that more than half (51.6\%) of the women did not circumcise their daughters yet and less than two thirds $(61.7 \%)$ of the women intend to circumcise their daughters in the future.

Figure 2 shows that less than two thirds $(63.0 \%)$ of the women had positive attitude towards combating FGC. Concerning benefits of FGC, $31.6 \%$ of the women had positive attitude compared to $61.0 \%$ of them who had positive attitude towards its harms. While, $36.4 \%$ of the women had positive attitude regarding societal and religious beliefs about FGC. On the other hand, $45 \%$ of the women had positive attitude towards own and community support of FGC.

Figure 3 illustrates that less than one tenth $(9.8 \%)$ of the women had low sexual satisfaction compared to $18.4 \%$ of had high satisfaction. While, less than three quarters (71.8\%) of the women had moderate sexual satisfaction.

Table 4 illustrated the correlation between the women's demographic characteristics and their attitude toward FGC. The table reveals a significant correlation between the women's age and their attitude towards FGC where positive attitude toward FGC was more prevalent among those aged less than thirty years compared to those aged more than 40 years $(74.0 \%$ and $72.5 \%$ respectively $)\left(\mathrm{X}^{2}=65.89 \mathrm{P}=0.000\right)$.

Furthermore, positive attitude toward FGC was more encountered among Christians and those women from urban areas $(73.3 \%$ and $64.9 \%$ respectively).

It was found that women's education and occupation had a significant effect on their attitude toward FGC $\left(\mathrm{X}^{2}=\right.$ $53.09 \mathrm{P}=0.000, \mathrm{X}^{2}=23.58 \mathrm{P}=0.000$ respectively), where positive attitude was more encountered among highly educated and working women ( $76.6 \%$ and $83.3 \%$ respectively).

The same table portrays that husbands' education and occupation had a significant effect on the women's attitude toward FGC $\left(\mathrm{X}^{2}=90.22 \mathrm{P}=0.000, \mathrm{X}^{2}=12.71 \mathrm{P}=0.000\right.$ respectively), where positive attitude was more encountered among highly educated and working husbands ( $76.6 \%$ and $83.3 \%$ respectively).

Additionally, positive attitude toward FGC was more encountered among those women from higher social class and those who reported income sufficiency $(73.6 \%$ and $71.5 \%$ respectively) with a statistically significant relation between attitude toward FGC and family social level and income sufficiency $\left(\mathrm{X}^{2}=71.43 \mathrm{P}=0.000, \mathrm{X}^{2}=\right.$ 46.18 $\mathrm{P}=0.000$ respectively).

Lastly, statistically significant relations were found between attitude toward FGC and circumcision of daughters and intention to do so in the future $\left(\mathrm{X}^{2}=37.95 \mathrm{P}=0.000, \mathrm{X}^{2}=13.54 \mathrm{P}=0.000\right.$ respectively) where positive attitude toward FGC was less prevalent among those women who circumcised their daughters and declared that they would do so in the future (59.3\% and $54.5 \%$ respectively).

Table 5 illustrated the correlation between the women's demographic characteristics and their sexual satisfaction. The table portrays a significant correlation between the women's age and their sexual satisfaction where high satisfaction was less encountered among those aged less than thirty years compared to those aged more than 40 years $(65.2 \%$ and $73.2 \%$ respectively $)\left(\mathrm{X}^{2}=114.75 \mathrm{P}=0.000\right)$.

Moreover, high sexual satisfaction was more prevalent among Christians and those women from urban areas (46.7\% and $28.0 \%$ respectively) with statistically significant relations between sexual satisfaction and religion and place of residence $\left(\mathrm{X}^{2}=17.88 \mathrm{P}=0.000, \mathrm{X}^{2}=61.31 \mathrm{P}=0.000\right.$ respectively $)$. 
It was noticed that women's education and occupation had a significant effect on their sexual satisfaction $\left(\mathrm{X}^{2}=\right.$ $74.03 \mathrm{P}=0.000, \mathrm{X}^{2}=222.90 \mathrm{P}=0.000$ respectively), where high sexual satisfaction was more encountered among highly educated and working women ( $43.5 \%$ and $43.9 \%$ respectively).

The same table portrays that husbands' education and occupation had a significant effect on the sexual satisfaction $\left(X^{2}=91.08 \mathrm{P}=0.000, X^{2}=23.21 \mathrm{P}=0.000\right.$ respectively), where low satisfaction was more encountered among illiterate and nonworking husbands ( $15.5 \%$ and $40.0 \%$ respectively).

Additionally, women's age at marriage has a significant effect on the women sexual satisfaction $\left(\mathrm{X}^{2}=324.82\right.$ $\mathrm{P}=0.000$ ) where low sexual satisfaction was more encountered among those women who married at age less than 20 years old (39.3\%) compared to $4.8 \%$ of those married at age 30 years and more. On the other hand, it was found that the larger the family size, the lower the sexual satisfaction as low sexual satisfaction was more encountered among those families with nine members and more compared to those families with three to five members $(15.0 \%$ and $8.8 \%$ respectively).

Lastly, statistically significant relations were found between sexual satisfaction and income sufficiency and family social level $\left(X^{2}=9.973 \mathrm{P}=0.000, \mathrm{X}^{2}=392.59 \mathrm{P}=0.000\right.$ respectively $)$ where low sexual satisfaction was less prevalent among those women from high social class and those who reported income sufficiency $(3.4 \%$ and $1.9 \%$ respectively).

Table 6 illustrated the correlation between the women's experience of FGC and their attitude toward FGC and sexual satisfaction.

The table reveals a significant correlation between the women's experience of FGC and their attitude towards FGC $(\mathrm{F}=33.138, \mathrm{P}=0.000)$ where total attitude toward FGC mean score was higher among non-circumcised women $(31.28 \pm 7.630)$ than circumcised women $(14.17 \pm 3.861)$.

Additionally, the total sexual satisfaction mean score was lower among circumcised women compared to non-circumcised women $(4.32 \pm 1.425$, and $6.227 \pm 2.691$ respectively) with a significant correlation between the women's experience of FGC and their sexual satisfaction $(\mathrm{F}=5.812, \mathrm{P}=0.000)$. 
Table 1. Distribution of the women according to their socio demographic characteristics

\begin{tabular}{|c|c|c|}
\hline \multirow[t]{2}{*}{ Subjects' characteristics } & \multicolumn{2}{|c|}{$\begin{array}{c}\text { Total } \\
\mathbf{N}=\mathbf{8 0 0}\end{array}$} \\
\hline & No & $\%$ \\
\hline \multicolumn{3}{|l|}{ Age (years) } \\
\hline$-20-$ & 362 & 45.2 \\
\hline$-30-$ & 296 & 37.0 \\
\hline$-40+$ & 142 & 17.8 \\
\hline $\mathrm{X} \pm \mathrm{SD}$ & \multicolumn{2}{|c|}{$32.45 \pm 7.203$} \\
\hline \multicolumn{3}{|l|}{ Religion } \\
\hline - Muslims & 770 & 96.2 \\
\hline - Christians & 30 & 3.8 \\
\hline \multicolumn{3}{|l|}{ Place of residence } \\
\hline - Urban & 436 & 54.5 \\
\hline - Rural & 364 & 45.5 \\
\hline \multicolumn{3}{|l|}{ Wife's level of education } \\
\hline - Illiterate / read \& write & 220 & 27.4 \\
\hline - Completed basic education & 108 & 13.6 \\
\hline - Completed secondary / technical education & 348 & 43.5 \\
\hline - Completed university education and more & 124 & 15.5 \\
\hline \multicolumn{3}{|l|}{ Wife's occupation } \\
\hline - Working & 114 & 14.3 \\
\hline - Non-working (housewife) & 686 & 85.7 \\
\hline \multicolumn{3}{|l|}{ Husband's level of education } \\
\hline - Illiterate / read \& write & 206 & 25.8 \\
\hline - Completed basic education & 68 & 8.4 \\
\hline - Completed secondary / technical education & 360 & 45.0 \\
\hline - Completed university education and more & 166 & 20.8 \\
\hline \multicolumn{3}{|l|}{ Husband's occupation } \\
\hline - Working & 780 & 97.5 \\
\hline - Non-working & 20 & 2.5 \\
\hline \multicolumn{3}{|l|}{ Wife's age at marriage(year) } \\
\hline$-<20$ & 150 & 18.7 \\
\hline$-20-$ & 464 & 58.0 \\
\hline$-30+$ & 186 & 23.3 \\
\hline $\mathrm{X} \pm \mathrm{SD}$ & \multicolumn{2}{|c|}{$21.65 \pm 3.245$} \\
\hline \multicolumn{3}{|l|}{ Duration of marriage (year) } \\
\hline$-<5$ & 302 & 37.8 \\
\hline$-5-$ & 136 & 17.0 \\
\hline$-10-$ & 132 & 16.5 \\
\hline$-15+$ & 230 & 28.7 \\
\hline $\mathrm{X} \pm \mathrm{SD}$ & \multicolumn{2}{|c|}{$10.13 \pm 7.635$} \\
\hline
\end{tabular}


Table 1 cont.

\begin{tabular}{|c|c|c|}
\hline & Items & $\begin{array}{c}\text { Total } \\
\mathbf{N}=\mathbf{8 0 0}\end{array}$ \\
\hline & No & $\%$ \\
\hline \multicolumn{3}{|l|}{ Family size } \\
\hline$-3-$ & 434 & 54.2 \\
\hline$-6-$ & 306 & 38.3 \\
\hline - 9+ & 60 & 7.5 \\
\hline $\mathrm{X} \pm \mathrm{SD}$ & \multicolumn{2}{|c|}{$4.52 \pm 1.348$} \\
\hline \multicolumn{3}{|c|}{ Income sufficiency } \\
\hline - Enough & 576 & 72.0 \\
\hline - Not enough & 224 & 28.0 \\
\hline \multicolumn{3}{|c|}{ Crowding index } \\
\hline$-<2$ & 774 & 96.8 \\
\hline-2 & 16 & 2.0 \\
\hline$->2$ & 10 & 1.2 \\
\hline \multicolumn{3}{|c|}{ Family social level } \\
\hline - Low & 122 & 15.3 \\
\hline - Middle & 500 & 62.5 \\
\hline - High & 178 & 22.2 \\
\hline
\end{tabular}

Table 2. Distribution of the studied women according to their experience of FGC

\begin{tabular}{|c|c|c|c|}
\hline & \multirow[t]{2}{*}{ Items } & \multicolumn{2}{|c|}{$\begin{array}{c}\text { Total } \\
\mathbf{N}=\mathbf{8 0 0}\end{array}$} \\
\hline & & No & $\%$ \\
\hline \multicolumn{4}{|l|}{ Experience of FGC } \\
\hline - Yes & & 720 & 90.0 \\
\hline - No & & 80 & 10.0 \\
\hline & Age at FGC & & \\
\hline$-<10$ & & 150 & 20.8 \\
\hline$-10-$ & & 385 & 53.5 \\
\hline$-15+$ & & 185 & 25.7 \\
\hline \multicolumn{4}{|l|}{ Who perform FGC } \\
\hline - Physician & & 252 & 35.0 \\
\hline - Nurse & & 140 & 19.4 \\
\hline - Daya/ TBA & & 278 & 38.6 \\
\hline - Health barber & & 50 & 6.9 \\
\hline \multicolumn{4}{|l|}{ Place of conducting FGC } \\
\hline - Home & & 576 & 80.0 \\
\hline - Private hospital/ clinic & & 137 & 19.0 \\
\hline - Governmental hospital & & 7 & 1.0 \\
\hline \multicolumn{4}{|l|}{ Opinion taken before FGC } \\
\hline - Yes & & 0 & 0.0 \\
\hline - No & & 720 & 100.0 \\
\hline \multicolumn{4}{|c|}{ Circumcised alone or with other girls } \\
\hline - Alone & & 502 & 69.7 \\
\hline - With other girls & & 218 & 30.3 \\
\hline Immediate reaction to FGC & & & \\
\hline
\end{tabular}




\begin{tabular}{|c|c|c|c|}
\hline \multirow{8}{*}{$\begin{array}{l}\text { - No } \\
\text { - Yes\# }\end{array}$} & & 432 & 60.0 \\
\hline & & 288 & 40.0 \\
\hline & - Pain & 216 & 75.0 \\
\hline & - Bleeding & 60 & 20.8 \\
\hline & - Fever & 48 & 16.7 \\
\hline & - Inflammation & 63 & 21.9 \\
\hline & - Urinary problems & 172 & 59.7 \\
\hline & - $\quad$ Fear and shock & 138 & 47.9 \\
\hline \multirow{3}{*}{\multicolumn{2}{|c|}{$\begin{array}{l}\text { Long term complications } \\
\text { - No } \\
\text { - Yes\# }\end{array}$}} & \multicolumn{2}{|c|}{$N=720$} \\
\hline & & 506 & 70.3 \\
\hline & & 214 & 29.7 \\
\hline & - Diminished sexual pleasure & 158 & 73.8 \\
\hline & - Dyspareunia & 102 & 47.7 \\
\hline & - Psychological problems & 72 & 33.6 \\
\hline & Urinary problems & 66 & 30.8 \\
\hline
\end{tabular}

\# Multiple answers were allowed

Table 3. Distribution of the studied women according to their daughters' experience of FGC

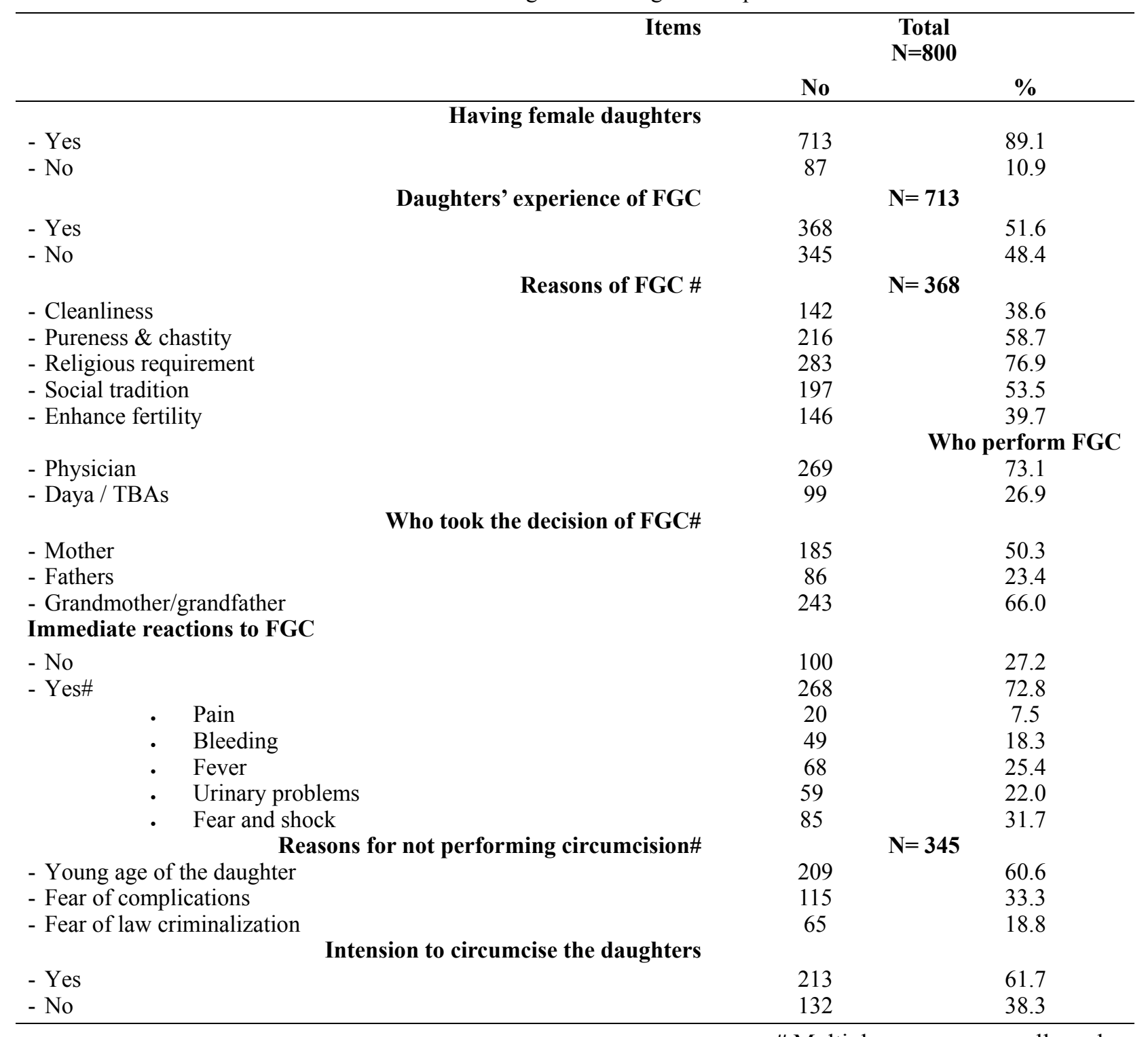

\# Multiple answers were allowed 


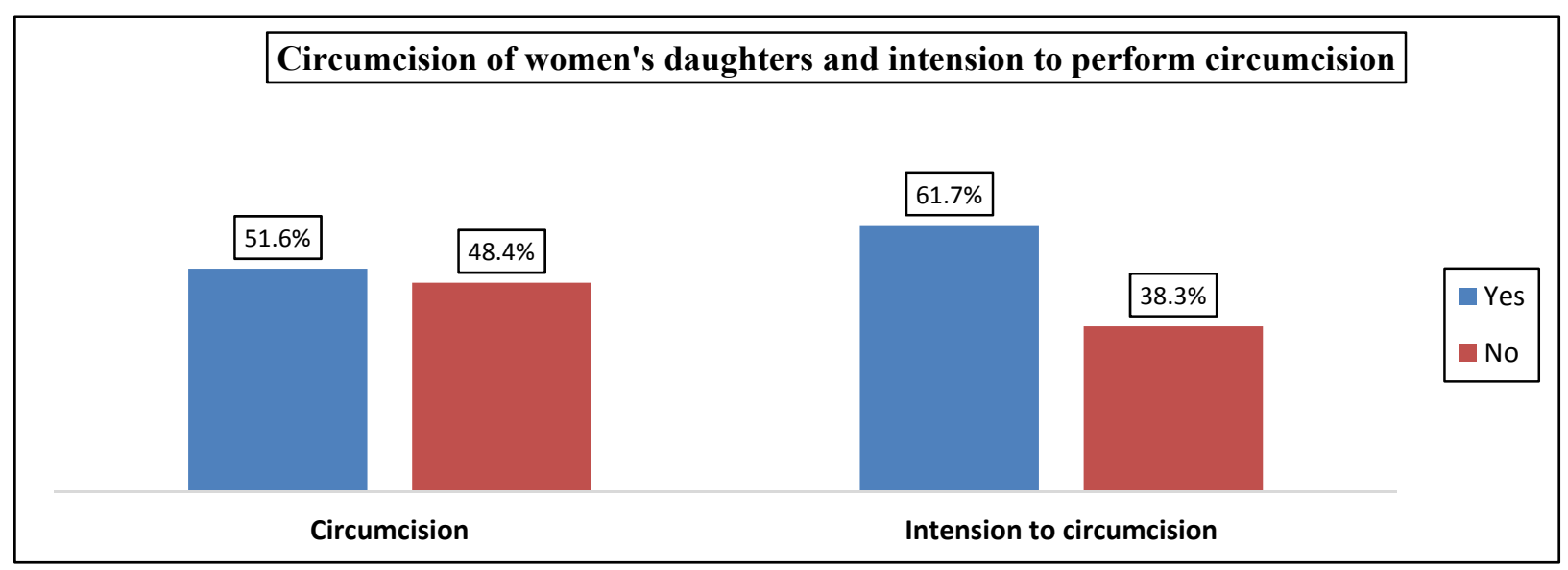

Figure 1. Distribution of the studied women according to their daughters' circumcision and intension to circumcision

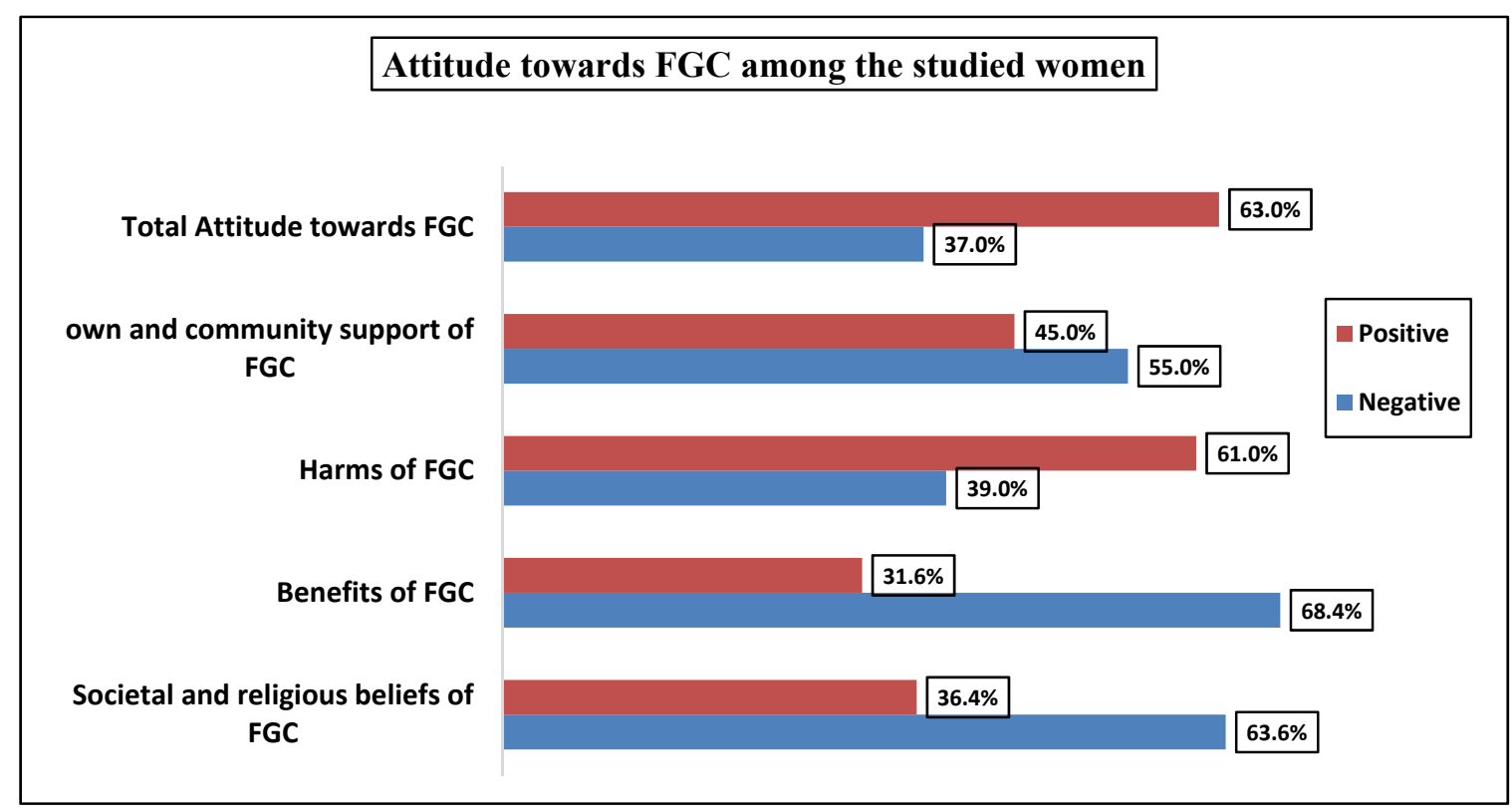

Figure 2. Distribution of the studied women according to their attitude towards FGC

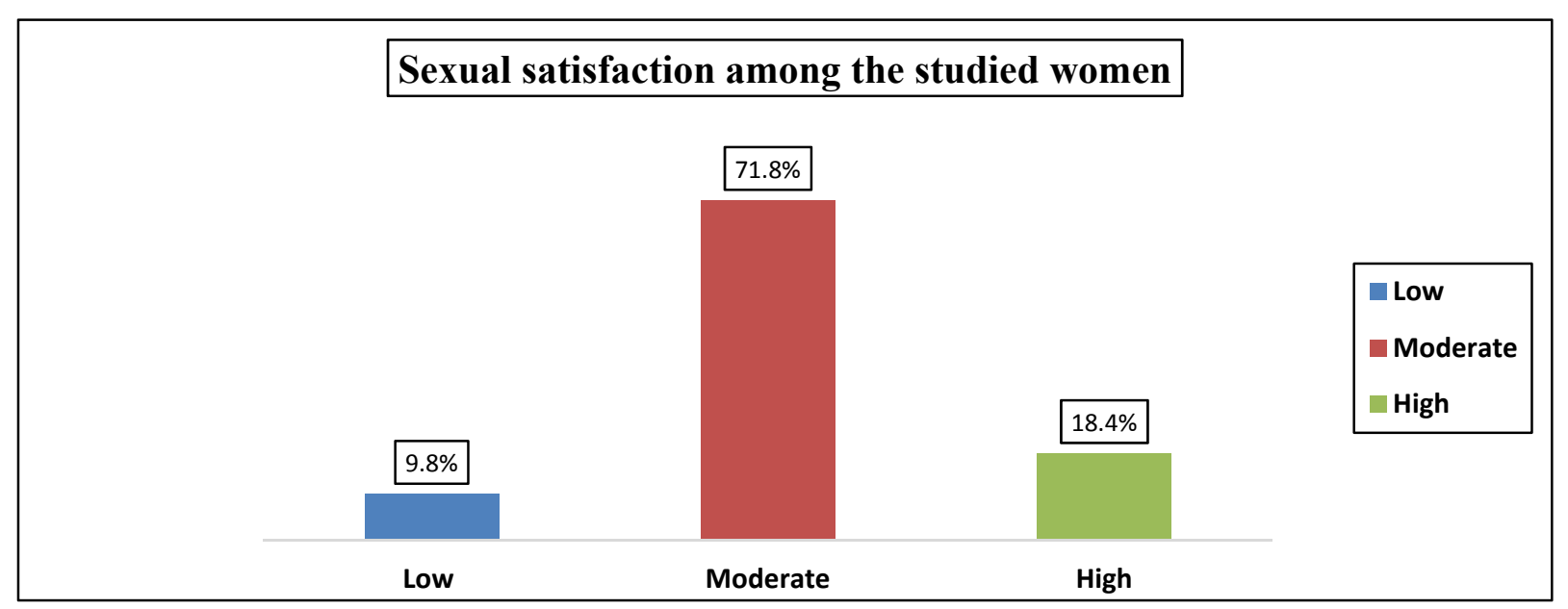

Figure 3. Distribution of the studied women according to their sexual satisfaction 
Table 4. Relation between the women's attitude towards FGC and their socio demographic characteristics

\begin{tabular}{|c|c|c|c|c|c|c|c|}
\hline \multirow[t]{3}{*}{ Items } & \multicolumn{4}{|c|}{ Attitude towards FGC } & \multirow{2}{*}{\multicolumn{2}{|c|}{$\begin{array}{c}\text { Total } \\
(\mathbf{N}=\mathbf{8 0 0})\end{array}$}} & \multirow{3}{*}{$\begin{array}{c}\text { Test of } \\
\text { significance }\end{array}$} \\
\hline & \multicolumn{2}{|c|}{$\begin{array}{c}\text { Negative } \\
\text { (those who } \\
\text { encourage FGC) } \\
(\mathbf{N}=\mathbf{2 9 6})\end{array}$} & \multicolumn{2}{|c|}{$\begin{array}{c}\text { Positive } \\
\text { (those who } \\
\text { discourage FGC) } \\
(\mathbf{N}=\mathbf{5 0 4})\end{array}$} & & & \\
\hline & No & $\%$ & No & $\%$ & \multirow[t]{2}{*}{ No } & \multirow[t]{2}{*}{$\%$} & \\
\hline Age (years) & & & & & & & \\
\hline$-20-$ & 94 & 26.0 & 268 & 74.0 & 362 & 45.2 & $X^{2}=65.89$ \\
\hline$-30-$ & 163 & 55.1 & 133 & 44.9 & 296 & 37.0 & $\mathrm{P}=0.000^{*}$ \\
\hline - $40+$ & 39 & 27.5 & 103 & 72.5 & 142 & 17.8 & \\
\hline \multicolumn{8}{|l|}{ Sex } \\
\hline - Muslims & 288 & 37.4 & 482 & 62.6 & 770 & 96.2 & $X^{2}=1.428$ \\
\hline - Christians & 8 & 26.7 & 22 & 73.3 & 30 & 8.3 & $\mathrm{P}=0.232$ \\
\hline \multicolumn{8}{|l|}{ Place of residence } \\
\hline - Urban & 153 & 35.1 & 283 & 64.9 & 436 & 54.5 & $X^{2}=1.497$ \\
\hline - Rural & 143 & 39.3 & 221 & 60.7 & 364 & 45.5 & $\mathrm{P}=0.221$ \\
\hline \multicolumn{8}{|l|}{ Women's education } \\
\hline - Illiterate / read \& write & 119 & 54.1 & 101 & 45.9 & 220 & 27.4 & $X^{2}=53.09$ \\
\hline - Basic education & 50 & 46.3 & 58 & 53.7 & 108 & 13.6 & $\mathrm{P}=0.000^{*}$ \\
\hline - Secondary education & 98 & 28.2 & 250 & 71.8 & 348 & 43.5 & \\
\hline - University education & 29 & 23.4 & 95 & 76.6 & 124 & 15.5 & \\
\hline \multicolumn{8}{|l|}{ Women's occupation } \\
\hline - Working & 19 & 16.7 & 95 & 83.3 & 114 & 14.3 & $X^{2}=23.58$ \\
\hline - Non-working (housewife) & 277 & 40.4 & 409 & 59.6 & 686 & 85.7 & $\mathrm{P}=0.000^{*}$ \\
\hline \multicolumn{8}{|l|}{ Husbands' education } \\
\hline - Illiterate / read \& write & 123 & 59.7 & 83 & 40.3 & 206 & 25.8 & $X^{2}=90.22$ \\
\hline - Basic education & 39 & 57.4 & 29 & 42.6 & 68 & 8.4 & $\mathrm{P}=0.000^{*}$ \\
\hline - Secondary education & 100 & 27.8 & 260 & 72.2 & 360 & 45.0 & \\
\hline - University education & 34 & 20.5 & 132 & 79.5 & 166 & 20.8 & \\
\hline \multicolumn{8}{|l|}{ Husband's occupation } \\
\hline - Working & 281 & 36.0 & 499 & 64.0 & 780 & 97.5 & $X^{2}=12.71$ \\
\hline - Non-working & 15 & 75.0 & 5 & 25.0 & 20 & 2.5 & $\mathrm{P}=0.000^{*}$ \\
\hline \multicolumn{8}{|l|}{ Income sufficiency } \\
\hline - Enough & 164 & 28.5 & 412 & 71.5 & 576 & 72.0 & $X^{2}=64.18$ \\
\hline - Not enough & 132 & 58.9 & 92 & 41.1 & 224 & 28.0 & $\mathrm{P}=0.000^{*}$ \\
\hline \multicolumn{8}{|l|}{ Family social level } \\
\hline - Low & 86 & 70.5 & 36 & 29.5 & 122 & 15.3 & $X^{2}=71.43$ \\
\hline - Middle & 163 & 32.6 & 337 & 67.4 & 500 & 62.5 & $\mathrm{P}=0.000^{*}$ \\
\hline - High & 47 & 26.4 & 131 & 73.6 & 178 & 22.3 & \\
\hline \multicolumn{8}{|l|}{ Circumcision of daughter } \\
\hline - Yes & 290 & 40.7 & 423 & 59.3 & 713 & 89.1 & $X^{2}=37.95$ \\
\hline - No & 6 & 6.9 & 81 & 93.1 & 87 & 10.9 & $\mathrm{P}=0.000^{*}$ \\
\hline $\begin{array}{l}\text { Intension to daughter's } \\
\text { circumcision }\end{array}$ & \multicolumn{2}{|c|}{$N=131$} & \multicolumn{2}{|c|}{$N=214$} & \multicolumn{2}{|c|}{$N=345$} & \\
\hline - Yes & 97 & 45.5 & 116 & 54.5 & 213 & 61.7 & $X^{2}=13.54$ \\
\hline - No & 34 & 25.8 & 98 & 74.2 & 132 & 38.3 & $\mathrm{P}=0.000^{*}$ \\
\hline
\end{tabular}


Table 5. Distribution of the studied women according to their sexual satisfaction and their socio demographic characteristics

\begin{tabular}{|c|c|c|c|c|c|c|c|c|c|}
\hline \multirow{4}{*}{ Age (years) } & \multicolumn{6}{|c|}{ Sexual Satisfaction } & \multirow{2}{*}{\multicolumn{2}{|c|}{$\begin{array}{c}\text { Total } \\
(\mathbf{N}=\mathbf{8 0 0})\end{array}$}} & \multirow{4}{*}{$\begin{array}{l}\text { Test } \\
\text { significance }\end{array}$} \\
\hline & \multicolumn{2}{|c|}{$\begin{array}{c}\text { Low } \\
(\mathrm{N}=78)\end{array}$} & \multicolumn{2}{|c|}{$\begin{array}{l}\text { Moderate } \\
(\mathrm{N}=574)\end{array}$} & \multicolumn{2}{|c|}{$\begin{array}{c}\text { High } \\
(\mathrm{N}=148)\end{array}$} & & & \\
\hline & No & $\%$ & No & $\%$ & & & No & $\%$ & \\
\hline & & & & & & & & & \\
\hline$-20-$ & 10 & 2.8 & 236 & 65.2 & 116 & 32.0 & 362 & 45.2 & $X^{2}=114.75$ \\
\hline$-30-$ & 36 & 12.2 & 234 & 79.1 & 26 & 8.8 & 296 & 37.0 & $\mathrm{P}=0.000^{*}$ \\
\hline$-40+$ & 32 & 22.5 & 104 & 73.2 & 6 & 4.2 & 142 & 17.8 & \\
\hline Religion & & & & & & & & & \\
\hline - Muslims & 78 & 10.1 & 558 & 72.5 & 134 & 17.4 & 770 & 96.2 & $X^{2}=17.88$ \\
\hline - Christians & 0 & 0.0 & 16 & 53.3 & 14 & 46.7 & 30 & 8.3 & $\mathrm{P}=0.000 *$ \\
\hline Place of residence & & & & & & & & & \\
\hline - Urban & 46 & 10.6 & 268 & 61.5 & 122 & 28.0 & 436 & 54.5 & $X^{2}=61.31$ \\
\hline - Rural & 32 & 8.8 & 306 & 84.1 & 26 & 7.1 & 364 & 45.5 & $\mathrm{P}=0.000^{*}$ \\
\hline Women's education & & & & & & & & & \\
\hline - Illiterate / read \& write & 24 & 10.9 & 180 & 81.8 & 16 & 7.3 & 220 & 27.4 & $X^{2}=74.03$ \\
\hline - Basic education & 12 & 11.1 & 82 & 75.9 & 14 & 13.0 & 108 & 13.6 & $\mathrm{P}=0.000 *$ \\
\hline - Secondary education & 30 & 8.6 & 254 & 73.0 & 64 & 18.4 & 348 & 43.5 & \\
\hline - University education & 12 & 9.7 & 58 & 46.8 & 54 & 43.5 & 124 & 15.5 & \\
\hline Women's occupation & & & & & & & & & \\
\hline - Working & 45 & 39.5 & 19 & 16.7 & 50 & 43.9 & 114 & 14.3 & $\mathrm{X}^{2}=222.90$ \\
\hline - Non-working (housewife) & 33 & 4.8 & 555 & 80.9 & 98 & 14.3 & 686 & 85.7 & $\mathrm{P}=0.000^{*}$ \\
\hline Husbands' education & & & & & & & & & \\
\hline - Illiterate / read \& write & 32 & 15.5 & 156 & 75.7 & 18 & 8.7 & 206 & 25.8 & $X^{2}=91.08$ \\
\hline - Basic education & 10 & 14.7 & 52 & 76.5 & 6 & 8.8 & 68 & 8.4 & $\mathrm{P}=0.000^{*}$ \\
\hline - Secondary education & 20 & 5.6 & 284 & 78.9 & 56 & 15.6 & 360 & 45.0 & \\
\hline - University education & 16 & 9.6 & 82 & 49.4 & 68 & 41.0 & 166 & 20.8 & \\
\hline Husband's occupation & & & & & & & & & \\
\hline - Working & 71 & 9.1 & 567 & 72.7 & 143 & 18.3 & 780 & 97.5 & $X^{2}=23.21$ \\
\hline - Non-working & 8 & 40.0 & 7 & 35.0 & 5 & 25.0 & 20 & 2.5 & $\mathrm{P}=0.000^{*}$ \\
\hline Wife's age at marriage & & & & & & & & & \\
\hline$-<20$ & 59 & 39.3 & 63 & 42.0 & 28 & 18.7 & 150 & 18.7 & $\mathrm{X}^{2}=324.82$ \\
\hline$-20-$ & 10 & 2.2 & 419 & 90.3 & 35 & 7.5 & 464 & 58.0 & $\mathrm{P}=0.000^{*}$ \\
\hline$-30+$ & 9 & 4.8 & 92 & 49.5 & 85 & 45.7 & 186 & 23.3 & \\
\hline Family size & & & & & & & & & \\
\hline$-3-$ & 38 & 8.8 & 306 & 70.5 & 90 & 20.7 & 434 & 54.3 & $X^{2}=5.218$ \\
\hline$-6-$ & 31 & 10.1 & 227 & 74.2 & 48 & 15.7 & 306 & 38.3 & $\mathrm{P}=0.265$ \\
\hline$-9+$ & 9 & 15.0 & 41 & 68.3 & 10 & 16.7 & 60 & 7.5 & \\
\hline Income sufficiency & & & & & & & & & \\
\hline - Enough & 11 & 1.9 & 476 & 82.6 & 89 & 15.5 & 576 & 72.0 & $X^{2}=9.973$ \\
\hline - Not enough & 67 & 29.9 & 98 & 43.7 & 59 & 26.3 & 224 & 28.0 & $\mathrm{P}=0.007 *$ \\
\hline Family social level & & & & & & & & & \\
\hline - Low & 52 & 42.6 & 50 & 41.0 & 20 & 16.4 & 122 & 15.3 & $\mathrm{X}^{2}=392.59$ \\
\hline - Middle & 20 & 4.0 & 450 & 90.0 & 30 & 6.0 & 500 & 62.5 & $\mathrm{P}=0.000^{*}$ \\
\hline - High & 6 & 3.4 & 74 & 41.6 & 98 & 55.1 & 178 & 22.3 & \\
\hline
\end{tabular}

$\mathrm{X}^{2}$ Chi square test * Significant at $\mathrm{P} \leq 0.05$ 
Table 6. Correlation between the mothers' experience of FGC, attitude towards FGC, their sexual satisfaction

\begin{tabular}{|c|c|c|c|c|}
\hline \multirow[t]{3}{*}{ Items } & \multicolumn{2}{|c|}{ Mothers' Circumcision } & \multirow{2}{*}{$\begin{array}{c}\text { Total } \\
(\mathbf{N}=\mathbf{8 0 0})\end{array}$} & \multirow[t]{3}{*}{ Test of significance } \\
\hline & $\begin{array}{c}\text { Yes } \\
(N=720)\end{array}$ & $\begin{array}{c}\text { No } \\
(\mathbf{N}=\mathbf{8 0})\end{array}$ & & \\
\hline & $\mathbf{X} \pm \mathrm{SD}$ & $\mathbf{X} \pm \mathbf{S D}$ & $\mathbf{X} \pm \mathbf{S D}$ & \\
\hline \multicolumn{5}{|l|}{ Attitude towards FGC } \\
\hline & $14.17 \pm 3.861$ & $31.28 \pm 7.630$ & $22.78 \pm 5.435$ & $\mathrm{~F}=33.138 \quad \mathrm{P}=0.000^{*}$ \\
\hline \multirow{2}{*}{ Sexual satisfaction } & & & & $E-5812 \quad D-0000 *$ \\
\hline & $4.32 \pm 1.425$ & $6.227 \pm 2.691$ & $11.36 \pm 3.412$ & $\mathrm{~F}=5.812 \quad \mathrm{P}=0.000^{*}$ \\
\hline
\end{tabular}

\section{Discussion}

Female Genital Cutting is a harmful practice which affects all aspects of women's health negatively. It is an extreme form of violence against women which impedes their ability to fully participate in public life, resulting in a disempowering effect on them. (UNFPA, 2018)

According to EHIS 2015 (El Zanaty 2015), 87\% of all Egyptian women age 15-49 years have undergone FGC reflecting the fact that FGC is still prevalent in the country. This high prevalence was noticed in the current study finding where the vast majority of the studied married females were circumcised.

Concerning the age at which females undergo FGC, it differs from one community to another. However, FGC is mostly carried out on young girls (UNICEF, 2016; WHO, 2018). In the present study, around three quarters of the circumcised women had undergone FGC at age less than 15 years. This was in accordance with the findings of Rasheed S et al (2011) and EHIS (2015) (El Zanaty 2015) where the highest percentages of the studied females were circumcised at age between nine to less than fifteen years old. The reasons for this practice in this young age are culture based include beliefs that it increases marriage opportunities, enhances fertility, and promotes purity, so it should be done as early as possible. It is viewed as a prerequisite for qualifying for wifehood (Tamire M\&Molla M, 2013).

Additionally, the current study findings revealed that none of the studied females were consulted before doing FGC and they were forced to undergo such harmful practice. This finding could be attributed to that in Arabian communities, women raised in a culture of silence marginalizing their opinions and their rights to express them. Additionally, FGC is usually conducted at a young age where little girls may not realize their rights to express their opinions or cannot make decisions that may affect them for the rest of their lives. Similar findings were reported by Hess R et al (2010) who found that more than half of subjects disagreed to undergone FGC. Moreover, Belda S et al (2017) found that the majority of the studied women were forced to undergo FGC.

Regarding the FGC's conductors, in the current study, it was noticed that less than two fifths of the women were circumcised by Dayas/ TBAs which shed the light on the danger role performed by daya or traditional birth attendance particularly among the rural population. Similar findings were reported by EHIS (2015) (El Zanaty 2015)., as Dayas were also responsible for 51.9\% of women's circumcision. Furthermore, Rasheed S et al (2011) found that the main perpetrator of this violent practice is Daya.

Concerning the place in which FGC was conducted, the current study revealed that majority of women had undergone FGC at their own homes. This result comes in agreement with Huidy K (2014) and Abo Baker R (2007) who reported that more than three quarters of older females' circumcision had been undertaken at homes. In fact, conducting FGC at homes is very dangerous, as at homes medical care are not available for the victims to undertake if any problem encountered which would worsen and complicate females' health condition with the probability of ending their lives. On the other hand, the study clarified that about one fifth of the women had been circumcised by physicians at private clinics or hospitals. This finding to some extent was similar to what Huidy K (2014) reported that around two thirds of studied subjects had FGC done at private clinics. Performing FGC at health care facilities is an attempt to avoid the harmful consequences of FGC, which have led to medicalization of the such practice. In fact, performance of FGC by health services providers constitutes a break in medical professionalism and ethical responsibility, as well as a violation of the law in most countries. Moreover, increasing trend of medicalization of FGC is considered as a great threat to the abandonment of the practice in many countries. ( UNFPA, 2007; Pearce A,\&Bewley S 2014).

FGC is a harmful experience, has may immediate and long-term consequences. The current study showed that two fifths of the studied women undergone FGC reported that they had suffered immediate or short-term 
problems. The most frequently mentioned problems were acute pain and urinary problem and psychological shock and fear. This result is expected as one of the FGC conductors is Daya/ TBA who did not use any anesthetic agents or follow any hygienic measures. Psychological trauma was a reaction to the way by which the victims were forced to undergo such dreadful procedure ( Abdel-Azim S 2013 ). This comes in line with Kizilhan J (2011) and Kentenich H (2008) who found that a considerable percentage of subjects experienced immediate complications after FGC. In fact, such findings have to be used to work hardly to raise people's awareness about FGC as inhuman and offensive practice and its harmful impacts on girls' and women's health.

In addition, the current study revealed that more than one quarter of circumcised women suffered long term complications, mainly sexual problems, as they reported having diminished sexual pleasure, dyspareunia and sexual dissatisfaction. These findings come in agreement with Adam T et al (2010), and Sharfi A et al (2013) who found that less than two thirds of circumcised women reported having dyspareunia and did not enjoy sexual intercourse.

Although women's sexual satisfaction is determined by several factors, but FGC is a key player. The current study found several significant factors correlates with women's sexual satisfaction like age, age at marriage and income sufficiency and social level, which were consistent with many researches (Abdel-Azim S 2013; Abd El-Naser $T$ et al 2010; Adam $T$ et al, 2010). The current study found a significant relation between female circumcision and sexual satisfaction, where high sexual satisfaction was more prevalent among uncircumcised women. This may attribute to that FGC entails removal of healthy organs like the clitoris and/or other sensitive parts of the female genitalia without any medical necessity impairing women's sexual functioning and reduces the female sexual response which may lead to anorgasmia and even frigidity (Alsibiani S\& Rouzi A,2010; Oyefara J 2015). Furthermore, undergoing such traumatic procedure which occurred in unclear and vague circumstances where little girls did not understand what was going on is a dreadful thing. Also, exposing their own bodies to strangers, who dealt with them in an aggressive way and hurt them, perpetuate those bitter feelings. FGC harmful memories and its accompanying shock and fear may retain with the women and portrays during sexual relations and reflected on their sexual satisfaction. This come in accordance with the study of Oyefara J (2015), Anis T et al (2012) and Andersson S et al (2012) who found that sexual functions were adversely affected among circumcised women. These findings prove that FGC may have negatively affected women's sexual quality of life and these findings have to be taken seriously, as it highlights the serious sexual impacts which make women suffer from such offensive practice depriving them from their sexual rights.

Despite of FGC immediate and long-term consequences, it is still acceptable among the Arabian communities. The current study findings reveal that more than half of the studied women circumcised their young daughters and a considerable proportion of those who did not perform it, expressed intention to circumcise their daughters in the future. Similar findings were reported by Hassanin I et al (2013) and Emam E et al (2011) who found that about three quarters of their subjects had already circumcised their daughters. This could be explained in that it seems that women's attitudes towards FGC had affected their decisions to abstain from subjecting their daughters to FGC (Lien I\& Schultz J 2013.) This was reflected in the current study findings, where the majority of those who did not circumcise their daughters or those who do not have intention to do it in the future had positive attitude towards discontinuation of FGC. These findings were in line with those of Afifi M (2017) who found that the intention to perform FGC to the daughters was higher among those women with negative attitude towards discontinuation of female genital cutting.

Furthermore, by looking at the underlying reasons for which women performed FGC for their daughters, it was noticed that the reasons reflecting the fact that culture has the upper hand in formulating people's beliefs in some occasions even where education gets higher. The current study revealed that the among the causes behind supporting FGC among the women were that it preserves girls' pureness and Chasity. In addition, large percentage of the studied women referred to FGC as a religious obligation as well as adherence to social traditions. This result is expected, as when people believe in something, they tend to ignore its harms or bad sides. In addition, FGC is a deeply rooted tradition which passed through from one generation to another despite its devastative effects on girls' and women's health. The inheritance and continuation of such harmful practice reflects the power of culture ( Edouard E,2013; UNFPA,2018). EDHS (2015) (El Zanaty F,2015) reported similar findings, as more than half of women thought that FGC is a religious requirement and less than half of them believed that the practice deters adultery. Furthermore, Yasin B et al (2013) reported that the common reasons for practicing FGC were cultural tradition and religion.

It was surprising to find that more than three quarters of the women in the current study believed that FGC is a religious requirement. In fact, some Muslims still consider FGC as a religious duty which was reflected in the present study where significant association was found between attitude towards FGC and religion where most of 
those who courage FGC were Muslims. FGC is practiced by Muslims and others, including Christian and Jewish. Thus, FGC is not confined to Islam. Moreover, Islam and other religions call for human dignity and body integrity instead of violating others' rights and committing violence where Quran and Sunnah don't include them (Asmani I\& Abdi M 2008). Such claim reflects lack of religious awareness and misunderstanding as well as misinterpretation of religious texts Thus, true interpretation of religious texts by trusted religious men is essential, as they play an important role in addressing and correcting such illness.

Concerning the women's attitude toward FGC, the present study found that less than two thirds of the women had positive attitudes toward FGC and wanted to combat it especially among those who had been circumcised before. This could be attributed to that the persons' own experience with FGC has a significant impact on formulating their attitudes. These findings come in line with those of Ali A (2012) who found a significant correlation between attitude toward FGC and previous experience of FGC.

Additionally, the current study found that the greater agreement and support for FGC was more prominent among older, rural dweller, less educated, non-working women and those of lower social level. This could be attributed to the fact that attitudes are shaped by peoples' culture in addition to several factors like level of education and social class. Level of education enables the person to be more receptive to new ideas and reject harmful practices and live healthier life. Furthermore, level of income and social class determine the environment in which the person live where believes and traditions play a role in courage or discourage harmful practices like FGC. So, within the rural environment, culture has a significant role in shaping the people's attitude and in turn their practices and in order to portray the full picture of FGC, the role of poverty, low awareness, illiteracy and low social class appear clearly. Such findings come in agreement with Yousef $\mathrm{F}$ et al (2017) and Koustuv D et al (2010) who reported that place of residence, education and social class had a significant correlation with the women approval of FGC.

\section{Conclusion}

Based upon the findings of the current study it could be concluded that FGC is a deeply rooted practice particularly among rural population. The majority of the studied women were circumcised at age less than fifteen years old. Moreover, less than two thirds of the studied women had positive attitude towards FGC and their attitude was significantly correlated with age, place of residence, religion, level of education and occupation as well with their social level. The current study found that less than one fifth of the studied women had high sexual satisfaction and several factors were significantly correlated with their satisfaction such as age, marriage' age, income sufficiency and social level. On the other hand, a significant association was found between the women's experience of FGC, attitude towards it and their sexual satisfaction.

\section{Recommendations}

- Raise public awareness about FGC and its legal situation while focusing on women's and girls' rights.

- Enforce the implementation of the laws and legislations which ensure girls' and women's rights and protect them from various forms of violence including FGC.

- Intensify Al Azhar efforts toward combating FGC through publicizing a clear statement on Al Azhar stand with respect to FGC and preparing qualified religious leaders who can convey the FGC abandonment message correctly, preparing and disseminating religious publications that provide arguments disproving the Islamic religious roots of FGC to delink this harmful practice from Islam.

Continue the efforts for empowering girls and women through education and participation economically and socially, using more innovative advanced approaches

\section{References}

Abd El-Naser, T., Farouk, A., El-Nashar, A., \& Mostafa, T. (2010). Sexual Side Effects Of Female Genital Mutilation/Cutting May Be Type Dependent: A Hospital-Based Study. Kasr Al-Aini Journal of Obstetrics \& Gynecology, 1(2), 65-74.

Abdel-Azim, S. (2013). Psychosocial and sexual aspects of female circumcision. African Journal of Urology, 19(3), 141-2. https://doi.org/10.1016/j.afju.2012.12.005

Abo Baker, R. (2009). Opinion of Women Regarding Prohibition and Criminalization of Female Genital Cutting. Unpublished master thesis. Faculty of Nursing, Alexandria: Alexandria University.

Adam, T., Bathija, H., Bishai, D., Bonnenfant, Y.T., Darwish, M., Huntington, D., et al. (2010). Estimating the obstetric costs of female genital mutilation in six African countries. Bull World Health Organ, 88(4), 281-8. https://doi.org/10.2471/BLT.09.064808 
Afifi, M. (2010). Egyptian ever married women's attitude towards discontinuation of female genital cutting. Singapore Med Journal, 51(1), 15- 20. Retrieved from https:/www.researchgate.net/publication/41722578

Ali, A. (2012). Knowledge and attitudes of female genital mutilation among midwives in Eastern Sudan. Reproductive Health, 9, 23. https://doi.org/10.1186/1742-4755-9-23

Alsibiani, S., \& Rouzi, A. (2010). Sexual function in women with female genital mutilation. Fertility and Sterility, 93(3), 722-4. https://doi.org/10.1016/j.fertnstert.2008.10.035

Andersson, S., Rymer, J., Joyce, D., Momoh, C., \& Gayle, C. (2012). Sexual quality of life in women who have undergone female genital mutilation: a case-control study. Bjog, 119(13), 1606-11. https://doi.org/10.1111/1471-0528.12004

Anis, T., Aboul Gheit, S., Awad, H., \& Saied, H. (2012, October). Effects of female genital cutting on the sexual function of Egyptian women. A cross-sectional study. $J$ Sex Med, 9(10), 2682-92. https://doi.org/10.1111/j.1743-6109.2012.02866.x

Asmani, I., \& Abdi, M. (2008). De-linking female genital mutilation/cutting from Islam. Washington, D.C: Population Council.

Belda, S., \& Kalu, A. (2017). Knowledge, Attitude and Practice of Mothers towards Female Genital Mutilation in South West Shoa Zone, Oromia Region, Ethiopia. MOJ Public Health, 6(2), 208-217. https://doi.org/10.15406/mojph.2017.06.00162

Berg, R., \& Denison, E.A. (2013). tradition in transition: factors perpetuating and hindering the continuance of female genital mutilation/cutting $(\mathrm{FGM} / \mathrm{C})$. Health Care Women Int, 34(10), 837-59. https://doi.org/10.1080/07399332.2012.721417

Byrne, A. (2013). Supporting women after genital mutilation. Nursing Times, 110(18), 12-4. Retrieved from https://www.nursingtimes.net/Journals/2014/04/25/u/q/n/300414-Supporting-women-after-genital-mutilatio n.pdf

Clark, M. (2008). Community health nursing: advocacy for population health (5th ed.). New Jersey: Pearson Education Hall.

Dalal, K., Lawoko, S., \& Jansson. (2010). Women's attitudes towards discontinuation of female genital mutilation in Egypt. Journal of Injury and Violence Research, 2(1), 41-7. https://doi.org/10.5249/jivr.v2i1.33

Edouard, E., Olatunbosun, O., \& Edouard, L. (2013). International efforts on abandoning female genital mutilation. African Journal of Urology, 19(3), 150-3. https://doi.org/10.1016/j.afju.2013.01.005

El Zanaty, F. (2015). Egypt Demographic and Health Survey 2015. Cairo, Egypt: Minstry of Health and Poulation, El Zanaty Associates. Retrieved from https://dhsprogram.com/pubs/pdf/FR313/FR313.pdf

Emam, E., EL-Maghawri, A., \& Labeeb, S. (2011). Cultural Awareness about Female Genital Mutilation among Female Employees of Minia University. Journal of American Science, 7(4). Retrieved from http://www.jofamericanscience.org/journals/am-sci/am0704/87_5297am0704_611_617.pdf

Guimei, M., Fikry, F.E., \& Esheiba, O.M. (2012). Patterns of violence against women in three communities in Alexandria, Egypt. The American Journal of Maternal Child Nursing, 37(5), 331-8. https://doi.org/10.1097/NMC.0b013e31825c99d8

Hassanin, I., \& Shaaban, O. (2013). Impact of the complete ban on female genital cutting on the attitude of educated women from Upper Egypt toward the practice. International Journal of Gynecology and Obstetrics, 120(3), 275-8. https://doi.org/10.1016/j.ijgo.2012.10.010

Hess, R., Weinland, J., \& Saalingar, N. (2010). Knowledge of Female Genital Cutting and Experience with Women Who are Circumcised: A Survey of Nurses and Midwives in the Unites States. Journal of Midwifery Women Health, 55(1), 46-54. https://doi.org/10.1016/j.jmwh.2009.01.005

Huidy, K. (2014). Intergenerational family's perception with respect to female genital in El Berolos District, Kafr El Sheikh Governorate. Unpublished master thesis. Faculty of Nursing, Alexandria University.

Kentenich, H. (2008). Female genital mutilation: an injury, physical and mental harm. Journal of Psychosomatic Obstetrics \& Gynecology, 29(4), 225-9. https://doi.org/10.1080/01674820802547087

Kizilhan, J. (2011). Impact of psychological disorders after female genital mutilation among Kurdish girls in Northern Iraq. European Journal of Psychiatry, 25(2), 92-100. http://dx.doi.org/10.4321/S0213-61632011000200004

Lien, I, \& Schultz, J. (2013). Internalizing knowledge and changing attitudes to female genital cutting/mutilation. Obstetrics and Gynecology International. https://doi.org/10.1155/2013/467028

McCrae, N., \& Bynoe, S. (2015). The role of community nurses in preventing female genital mutilation. Primary 
Health Care, 25(2), 30-3. https://doi.org/10.7748/phc.25.2.30.e937

Oyefara, J. (2015). Female genital mutilation (FGM) and sexual functioning of married women in Oworonshoki Community, Lagos State, Nigeria. African Population Studies, 29(1), 1527-41. https://doi.org/10.11564/29-1-696

Pearce, A., \& Bewley, S. (2014). Medicalization of female genital mutilation. Harm reduction or unethical?. Obstetrics, Gynecology \& Reproductive Medicine, 24(1), 29-30. https://doi.org/10.1016/j.ogrm.2013.11.003

Rasheed, S., Abd-Ellah, A., \& Yousef, F. (2011). Female genital mutilation in Upper Egypt in the new millennium. Int J Gynaecol Obstet, 114(1), 47-50. https://doi.org/10.1016/j.ijgo.2011.02.003

Sharfi, A., Elmegboul, M., \& Abdella, A. (2013). The continuing challenge of female genital mutilation in Sudan. African Journal of Urology, 19(3), 136-40. https://doi.org/10.1016/j.afju.2013.06.002

Tamire, M., \& Molla, M. (2013). Prevalence and belief in the continuation of female genital cutting among high school girls: a cross - sectional study in Hadiya zone, Southern Ethiopia. BMC Public Health, 13, 1120-7. https://doi.org/10.1186/1471-2458-13-1120

UNFPA. (2007). A Holistic Approach to the Abandonment of Female Genital Mutilation/Cutting. New York: UNFPA.

Retrieved

from https://www.unfpa.org/publications/holistic-approach-abandonment-female-genital-mutilationcutting

UNFPA. (2018). Eliminating Female Genital Cutting and other practices harmful to women. Retrieved 10 September, 2018 , http://www.unfpa.org/resources/eliminating-femalegenital-cutting-and-other-practices-harmful-women

UNICEF. (2013). Female genital mutilation/cutting: A statistical overview and exploration of the dynamics of change. New York: UNICEF. Retrieved from https://www.unicef.org/publications/index_69875.html

UNICEF. (2016). Female Genital Mutilation/Cutting: A Global Concern. New York: UNICEF. Retrieved from https://data.unicef.org/resources/female-genital-mutilationcutting-global concern/

UNICEF. (2018). Female Genital Mutilation and Cutting: Current status and progress. Retrieved 24 November, 2018, from http://data.unicef.org/child-protection/fgmc.html

United Nations. (2014). Women's rights are human rights. Geneva: United Nations. Retrieved from https://www.ohchr.org/Documents/Events/WHRD/WomenRightsAreHR.pdf

United Nations. (2018). Ending Violence Against Women and Girls. Retrieved 5 November, 2018, from http://www.un.org/en/globalissues/briefingpapers/endviol/

United Nations. (2018). Ending Violence Against Women and Girls. Retrieved 24 September, 2018, from http://www.un.org/en/globalissues/briefingpapers/endviol/

Varol, N., Fraser, I., Ng, C., Jaldesa, G., \& Hall, J. (2014). Female genital mutilation/cutting - towards abandonment of a harmful cultural practice. The Australian \& New Zealand Journal of Obstetrics \& Gynaecology, 54(5), 400-5. https://doi.org/10.1111/ajo.12206

WHO. (2018). Female genital mutilation. Retrieved 25 August, 2018, from http://www.who.int/mediacentre/factsheets/fs241/en/

WHO. An update on WHO's work on female genital mutilation (FGM). (2011). Geneva: WHO. Retrieved from https://www.who.int/reproductivehealth/publications/fgm/rhr_11_18/en/

Yasin, B., Al-Tawil, N., Shabila, N., \& Al-Hadithi, T. (2013). Female genital mutilation among Iraqi Kurdish women: a cross-sectional study from Erbil city. BMC Public Health, 13(1), 809. https://doi.org/10.1186/1471-2458-13-809

Yirga, W., Kassa, N., Welday, M., \& Gebremichael, Aro A. (2012). Female genital mutilation: prevalence, perceptions and effect on women's health in Kersa district of Ethiopia. International Journal of Women's Health, 4, 45-54. https://doi.org/10.2147/IJWH.S28805

Yousef, F., Hamed, A., \& Mostafa, N. (2017). Female Genital Cutting: Prevalence, knowledge and attitude of Sohage University level Students, Upper Egypt. The Egyptian Journal of Community Medicine, 35(1), 17-25. https://doi.org/10.21608/ejcm.2017.2808

\section{Copyrights}

Copyright for this article is retained by the author(s), with first publication rights granted to the journal.

This is an open-access article distributed under the terms and conditions of the Creative Commons Attribution license (http://creativecommons.org/licenses/by/4.0/). 